JURNAL ILMIAH MANAJEMEN BISNIS DAN INOVASI UNIVERSITAS SAM RATULANGI (JMBI UNSRAT)

\title{
DAMPAK PENERAPAN REMUNERASI, MANAJEMEN PERUBAHAN DAN BUDAYA ORGANISASI TERHADAP KINERJA PEGAWAI (STUDI PADA PEGAWAI RSUP PROF DR. R.D. KANDOU MANADO)
}

\author{
Deisy Sandra Megawe, Silvya Mandey, Irvan Trang
}

Universitas Sam Ratulangi

A R T I C L E I N F O

Keywords : Remuneration, Change Management, Organization Cultures, RSUP

Prof. Dr. R. D. Kandou Manado

Kata Kunci Remunerasi, Manajemen Perubahan, Budaya Organisasi, RSUP Prof. Dr. R. D. Kandou Manado

\section{Corresponding author:}

Deasy Sandra Megawe deisymegawe@gmail.com
Abstract : The organization in the era of globalization increasingly rapidly make competition in an organization is tight. Organization of the government can optimize sued for human resources and how to manage human resources. Employees are the key for organization, wealth where they will be planner implementation and control are an active role in creating the organization. Employees have mind feelings and desires that might affect on the work he was doing this attitude will determine how much love of working for him to loyalty to the organization. The purpose of this study is to find the influence of the application of remuneration, change management and organization cultural on the employee performance RSUP Prof. Dr. R.D. Kandou Manado. This research take 60 a sample of respondents in RSUP Prof. Dr. R.D. Kandou Manado, using economic research to get a response to statement and using analysis multiple linear regression assisted a statistical analysis. The results obtained the research is together there are significant influence between remuneration, change management and cultural against the employee performance of organization. A partial remuneration significant against the employee performance, change management influential significantly against the employee performance is the positive and significant between organization cultures against the employee performance RSUP Prof. Dr. R.D. Kandou Manado.

Abstrak : Perkembangan organisasi di era globalisasi yang semakin pesat membuat persaingan dalam suatu organisasi pun semakin ketat. Organisasi Pemerintah dituntut untuk dapat mengoptimalkan sumber daya manusia dan bagaimana mengelolah sumber daya manusia. Pegawai merupakan kekayaan utama bagi organisasi, di mana mereka akan menjadi perencana, pelaksana dan pengendali yang selalu memberikan peran aktif dalam mewujudkan tujuan organisasinya. Pegawai mempunyai pikiran, perasaan dan keinginan yang dapat mempengaruhi sikap-sikapnya terhadap pekerjaan yang dilakukannya. Sikap ini akan menentukan seberapa besar kecintaannya terhadap pekerjaan yang dibebankan kepadanya, loyalitasnya kepada organisasi. Tujuan dari penelitian ini adalah untuk mengetahui pengaruh antara Penerapan Remunerasi, Manajemen Perubahan dan Budaya Organisasi terhadap kinerja pegawai RSUP Prof. Dr. R. D. Kandou Manado. Penelitian ini mengambil sampel 60 Responden yang ada di RSUP Prof. Dr. R. D. Kandou Manado dengan menggunakan angket penelitian untuk mendapatkan tanggapan atas pernyataan, selanjutnya menggunakan analisis regresi linear berganda dibantu alat analisis statistik. Hasil yang didapatkan dalam penelitian ini adalah Secara bersama terdapat pengaruh yang signifikan antara Remunerasi, Manajemen Perubahan dan Budaya Organisasi terhadap Kinerja Pegawai. Secara Parsial Remunerasi berpengaruh signifikan terhadap Kinerja Pegawai. Manajemen Perubahan berpengaruh secara signifikan terhadap Kinerja Pegawai. Terdapat pengaruh positif dan signifikan antara Budaya organisasi terhadap Kinerja Pegawai RSUP Prof. Dr. R. D. Kandou Manado 


\section{PENDAHULUAN}

Perkembangan organisasi diera globalisasi yang semakin pesat membuat persaingan dalam suatu organisasi pun semakin ketat. Sumber daya manusia memiliki peran penting dalam persaingan bisnis saat ini. Hal ini membuktikan bahwa kualitas sumber daya manusia juga menentukan kualitas dan masa depan perusahaan. Organisasi Pemerintah dituntut untuk dapat mengoptimalkan sumber daya manusia dan bagaimana mengelolah sumber daya manusia. Dalam pemeliharaan dan pengelolahan sumber daya manusia itu sendiri tentu harus mendapatkan perhatian yang lebih. Sumber daya manusia adalah salah satu faktor yang berperan penting untuk kelangsungan organisasi pemerintahan.

Pegawai merupakan kekayaan utama bagi organisasi, di mana mereka akan menjadi perencana, pelaksana dan pengendali yang selalu memberikan peran aktif dalam mewujudkan tujuan organisasinya. Pegawai mempunyai pikiran, perasaan dan keinginan yang dapat mempengaruhi sikap-sikapnya terhadap pekerjaan yang dilakukannya. Sikap ini akan menentukan seberapa besar kecintaannya terhadap pekerjaan yang dibebankan kepadanya, loyalitasnya kepada organisasi.

Globalisasi ditandai dengan perubahan pada tata kehidupan manusia. Abad ke-21 adalah abad yang menuntut segala usaha dan hasil kerja manusia termasuk dibidang organisasi. Ducker (2001:4) menyatakan tantangan manajemen abad ke-21 adalah berkaitan dengan "knowledge worker", yang memerlukan paradigma manajemen baru, strategi baru, pemimpin perubahan, tantangan informasi, produktivitas pegawai berbasis pengetahuan dan kemampuan mengelola diri sendiri.

Untuk mewujudkan hal tersebut diatas, diperlukan pemerintahan yang baik (good governance). Aparatur Negara sebagai pelayan masyarakat dituntut untuk dapat memberikan pelayanan publik yang berkualitas dari birokrat yang dilakukan secara transparan dan akuntabilitas. Sumber daya manusia diharapkan bukan dari segi kuantitas akan tetapi dari segi kualitas.

Suatu organisasi terlepas dari bentuk dan tujuannya, memiliki sasaran dan target yang telah ditetapkan untuk dicapai. Orang mendirikan organisasi karena beberapa tujuan tertentu hanya dapat dicapai lewat tindakan yang harus dilakukan. Artinya organisasi itu mengejar tujuan dan sasaran yang dapat dicapai secara efektif dan lebih efisien (Gibson 1990:3). Lebih lanjut dikatakan bahwa hasil keorganisasian tersebut tergantung dari hasil karya individu dan kelompok. Perilaku manusia baik individu dan kelompok, pengaturan dan mekasinme kerja seperti sistem, prosedur, dan metode kerja dalam organisasi publik belum sepenuhnya dimiliki karena dalam kenyataannya masih banyak pegawai yang kinerjanya kurang optimal dan menjadi penghambat dalam pencapaian tujuan organisasi, seperti kurang baiknya perilaku pegawai, lemahnya pengaturan dan mekanisme kerja, sarana prasarana yang belum memadai, kurangnya motivasi kerja, dan kualitas pegawai belum memadai seiring dengan perkembangan teknologi.

Persoalan kinerja pegawai akan dapat terlaksana apabila terdapat variable-variabel selain yang telah dikemukan diatas terpenuhi yaitu remunerasi, manajemen perubahan dan budaya organisasi. Dapat dikatakan bahwa agar pegawai selalu konsisten dan bertanggung jawab dalam setiap pekerjaannya, organisasi selalu memperhatikan lingkungan dimana pegawai melaksanakan tugasnya misalnya suasana kerja, pimpinan, kesejahteraan, rekan kerja dan hal-hal lain yang dapat mempengaruhi kemampuan seseorang dalam menjalankan tugasnya.

Remunerasi merupakan imbalan atau balas jasa yang diberikan kepada tenaga kerja atau pegawai sebagai akibat dari prestasi yang telah diberikannya. (Sofa 2008). Remunerasi mempunyai makna lebih luas dari pada gaji karena mencakup imbalan, baik yang berbentuk uang ataupun barang, baik yang diberikan secara langsung ataupun tidak langsung, dan baik yang bersifat rutin maupun tidak rutin.

Prinsip dasar remunerasi berbasis kinerja adalah adil dan proporsional, maka dengan kebijakan remunerasi berbasis kinerja, besar penghasilan (reward) yang diterima oleh seorang pegawai akan sangat ditentukan oleh bobot dan harga jabatan yang disandangnya serta kinerja yang telah dicapainya (Sangadji 2015:3). Seseorang yang berkinerja baik maka akan memperoleh imbalan yang lebih tinggi dan begitu pula 
sebaliknya. Artinya semakin tinggi kinerja yang diraih pegawai akan semakin tinggi pula imbalannya. Dalam menjalankan pelayanan, Rumah Sakit dihadapkan dengan tantangan-tantangan dimana semakin tinggi tuntutan masyarakat dalam pelayanan kesehatan dan tak bisa dipungkiri masih banyak keluhankeluhan yang diterima Rumas Sakit dalam hal pelayanan.

Peningkatan pelayanan kesehatan di rumah sakit sangat dipengaruhi oleh dukungan kinerja pegawai yang baik. Rumah Sakit Umum Pusat Prof. Dr. R. D. Kandou Manado sebagai instansi yang menerapkan Pola Pengelolaan Keuangan Badan Layanan Umum (PPK BLU), maka berdasarkan Peraturan Pemerintah Nomor 23 Tahun 2005 Pasal 36 disebutkan bahwa pejabat pengelola, dewan pengawas dan pegawai Badan Layanan Umum rumah sakit dapat diberikan remunerasi. Permenkeu No. 10/PMK.02/2006 Tentang Pedoman Penetapan Remunerasi Bagi Pejabat Pengelola, Dewan Pengawas dan Pegawai Badan Layanan Umum dapat diberikan remunerasi berdasarkan tingkat tanggung jawab dan tuntutan profesionalisme yang diperlukan. Dan ditegaskan dengan Kepmenkes No. 625/Menkes/SK/V/2010 Tentang Pedoman Penyusunan Sistem Remunerasi Pegawai BLU Rumah Sakit.

Manajemen Perubahan adalah suatu proses secara sistematis dalam menerapkan pengetahuan, sarana, dan sumber daya untuk mempengaruhi perubahan pada orang yang akan terkena dampak dari proses tersebut. Potts dan Lamarsh (2004:16). Perubahan akan selalu berubah dan tidak ada yang abadi di dunia ini selain perubahan itu sendiri. Menurut Hussey faktor pendorong terjadinya perubahan adalah perubahan teknologi yang terus meningkat persaingan semakin intensif dan menglobal, pelanggan semakin banyak tuntutan, profil demografis negara berubah, privatisasi bisnis masyarakat berlanjut, dan stakeholders minta lebih banyak nilai. Semua organisasi harus berubah dan mengembangkan diri dikarenakan adanya tekanantekanan terhadap organisasi, individu, atau kelompok (Lawin, 1997). Walaupun perubahan yang terjadi lebih pada lingkungan, namun menuntut perubahan lebih pada sisi organisasi. Organisasi bisa merubah tujuan, strategi, teknologi, desain pekerjaan, struktur, proses, dan orang. Perubahan pada orang senantiasa mendampingi perubahan pada sisi organisasi. Individu yang ingin karirnya berkembang harus dapat mengubah cara berfikir dan bertingkah laku menjadi lebih baik. Sementara itu pemimpin yang memfasilitasi manajemen perubahan kepada pegawai harus menentukan apa yang ingin diubah serta merumuskan tujuan perubahan itu sendiri, dimana pada langkah ini pemimpin harus sanggup membangun visi dan strategi agar perubahan lebih terarah, agar dapat terjadi peningkatan terhadap kinerja pegawai menjadi lebih baik.

Budaya organisasi merupakan seperangkat nilai-nilai yang menjadi karakteristik atau ciri suatu organisasi untuk menjadi acuan dalam menjalankan tujuan utama organisasi dan untuk memecahkan permasalahan organisasi. Budaya mengandung falsafah, ideology, nilai-nilai, anggapan, keyakinan, harapan, sikap dan norma-norma yang dinilai secara bersama serta mengikat dalam suatu komunitas tertentu. Kinerja pegawai sangat dipengaruhi oleh budaya organisasi, dari budaya organisasi yang kondusif dapat meningkatkan kinerja para pegawai. Kinerja pegawai yang efektif dan efisien akan mencerminkan kinerja organisasi dan membentuk citra organisasi. Robbins (1996) mengemukakan organisasi yang berbudaya kuat akan memiliki ciri khas tertentu sehingga dapat memberikan daya tarik bagi individu untuk bergabung, berfikir, bertindak dan berperilaku sesuai dengan nilai-nilai organisasi. Sehingga budaya organisasi dapat di simpulkan sebagai nilai-nilai yang menjadi pegangan sumber daya manusia dalam menjalankan kewajibanya dan juga perilakunya di dalam suatu organisasi.

Kinerja Pegawai adalah kesediaan seseorang atau kelompok untuk melakukan sesuatu kegiatan dan menyempurnakannya sesuai dengan tanggung jawabnya dengan hasil seperti yang di harapkan. Jika di kaitkan dengan performance sebagai kata benda (noun) di mana salah satu entrinya adalah hasil dari suatu pekerjaan (thing done), pengertian performance atau kinerja adalah hasil kerja yang dapat di capai oleh seseorang dalam suatu perusahaan secara legal, tidak melanggar hukum dan tidak bertentangan dengan moral atau etika (Rivai, 2005: 15-17). Kinerja pegawai merupakan hasil kerja secara kualitas dan kuantitas yang di capai oleh seorang pegawai dalam melaksanakan tugasnya sesuai dengan tanggung jawab yang 
diberikan kepadanya. Kinerja sesorang dapat diukur dari karakteristik individu seperti jenis kelamin, umur, pendidikan, masa kerja, asal tempat dan golongan jabatan, pria dan wanita memiliki perbedaan dalam kinerja pegawai dilihat dari kehadiran, disiplin. Faktor-faktor yang mempengaruhi kinerja pegawai meliputi strategi organisasi, (nilai tujuan,jangka pendek dan jangka panjang, budaya organisasi dan kondisi ekonomi) dan atribut individual antara lain kemampuan dan ketrampilan. Kinerja adalah hasil kerja secara kualitas dan kuantitas yang dicapai seorang pegawai dalam melaksanakan tugasnya sesuai dengan tanggung jawab yang diberikan kepadanya (Anwar Prabu Mangkunegara 2009:67). Sherman and Ghomes(2007:279 “Job performance is the amount of succesfullnrole achievenment'(Prestasi kerja / kinerja adalah jumlah /ukuran keberhasilan atas sesuatu yang dicapai). Menurut Soelaiman (2007:279) memberikan pengertian atas kinerja adalah sebagai sesuatu yang dikerjakan dan dihasilkan dalam bentuk produk maupun jasa, dalam suatu periode tertentu dan ukuran tertentu oleh sesorang atau kelompok orang melalui kecakapan, kemampuan, pengetahuan dan pengalamannya. Selanjutnya menururt Solaiman juga menjelaskan (2007:238) kinerja karyawan (employee performance) adalah tingkat terhadap karyawan mencapai persyaratan-persyaratan pekerjaan.

Rumah Sakit Umum Prof. Dr. R. D. Kandou Manado merupakan salah satu Rumah Sakit Vertikal dari Pemerintah Pusat di bawah binaan Kementerian Kesehatan Republik Indonesia dan berada di kota Manado Provinsi Sulawesi Utara. Rumah Sakit Umum Prof. Dr. R. D. Kandou Manado merupakan Rumah Sakit kelas A yang terakreditasi internasional. Jangkauan pelayanan rumah sakit bukan hanya untuk Provinsi Sulawesi Utara tetapi juga meliputi wilayah Indonesia Bagian Timur. Adapun status Rumah Sakit Umum Prof. Dr. R. D. Manado saat ini menjadi Instansi Pemerintah yang menerapkan pola pengelolaan keuangan BLU berdasarkan Peraturan Pemerintah No. 23 tahun 2005 dan telah diperbaharui dengan Peraturan Pemerintah No. 74/2012, serta Surat Keputusan Menteri Kesehatan No. 756/Menkes/SK/VI/ 2007 tentang Penetapan 15 Rumah Sakit Unit Pelaksana Teknis dengan menerapkan Pola Pengelolaan Keuangan BLU. Walaupun status sebagai Badan Layanan Umum masih mendapat subsidi dari pemerintah untuk biaya operasional dan belanja modal. Rumah Sakit Umum Prof. Dr. R. D. Kandou Manado adalah jalinan dari banyak simpul bisnis. Sebut saja bisnis hotel dalam kamar rawat inap, bisnis ritel pada apotek, bisnis transportasi dalam pelayanan ambulan, bisnis katering dalam gizi dan bisnis jasa pada pelayanan medis yang merupakan tulang punggung. RSUP Prof. Dr. R. D. Kandou Manado adalah Institusi Pelayanan Kesehatan yang menyelenggarakan kegiatan pelayanan kesehatan perorangan secara paripurna dengan mengutamakan kuratif dan rehabilitasi tanpa mengabaikan promotif dan preventif penyakit yang dilaksanakan melalui penyediaan pelayanan rawat jalan, rawat inap, rawat darurat dan rawat khusus. RSUP Prof. Dr. R. D. Kandou Manado merupakan satuan kerja Kementerian Kesehatan yang memberikan pelayanan kepada masyarakat, dan mempunyai tugas menyelenggarakan upaya penyembuhan dan pemulihan secara paripurna, menyelenggarakan pendidikan dan pelatihan, penelitian dan pengembangan secara serasi, terpadu dan berkesinambungan, menyelenggarakan upaya peningkatan kesehatan lainnya, dan melaksanakan rujukan. 
Adapun Gambaran umum tentang jumlah kunjungan pasien dimana bisa menggambarkan kinerja pegawai dapat dilihat pada Tabel berikut :

Gambar 1.1. Jumlah Kunjungan Pasien Tahun 2018

\section{JUMLAH KUNJUNGAN PASIEN RAWAT JALAN}

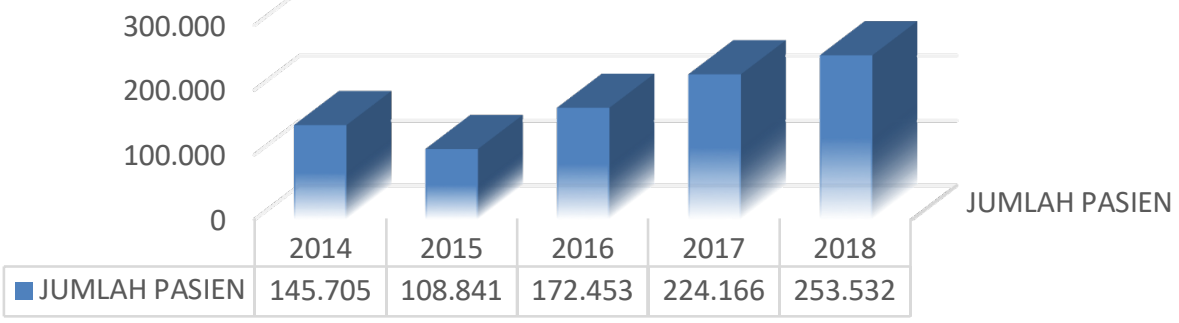

Sumber : RS Prof.Dr. R.D.Kandou Manado (2018)

Dari gambar di atas dapat dilihat bahwa kunjungan pasien rawat jalan dari tahun 2014 sampai tahun 2018 meningkat. Pada tahun 2015 terjadi penurunan kunjungan pasien rawat jalan dikarenakan adanya penerapan sistem rujukan dari BPJS sesuai dengan tingkat keparahan serta pada tahun 2017 adanya kenaikan karena penambahan layanan.

Gambar 1.2. Jumlah Pasien Rawat Inap

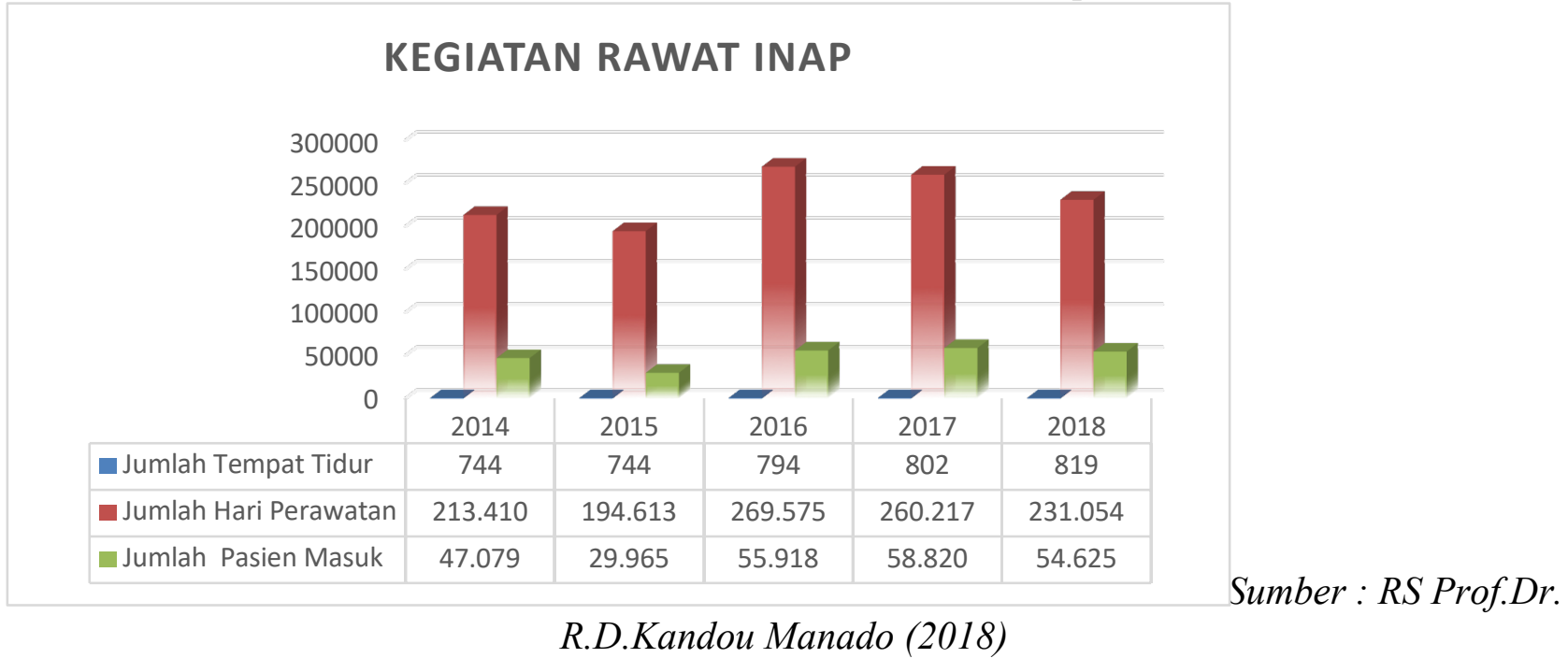

Dari tabel di atas dapat dilihat untuk jumlah hari perawatan tahun 2014 mengalami peningkatan senilai 3.888 hari perawatan atau 1,8\% dibandingkan jumlah hari perawatan tahun sebelumnya. Untuk jumlah pasien masuk mengalami kenaikan 15.324 pasien atau 34,65\% dibandingkan jumlah pasien masuk tahun sebelumnya.

Gambar 1.3. Jumlah Gawat Darurat 


\section{JUMLAH KEMATIAN DI GAWAT DARURAT}

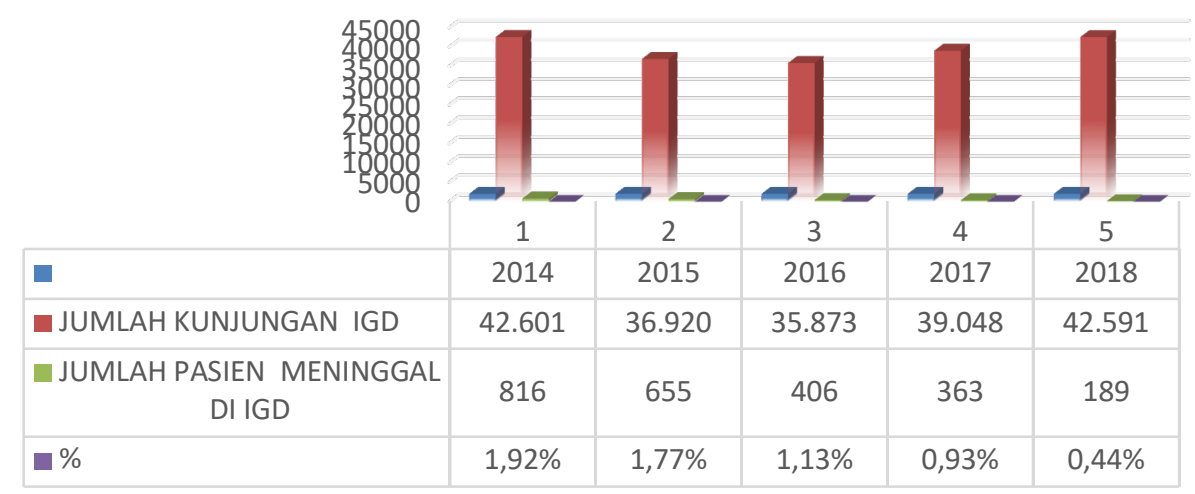

Sumber : RS Prof.Dr. R.D.Kandou Manado (2018)

Pada tahun 2014, jumlah kematian di IGD mengalami peningkatan seiring dengan bertambahnya jumlah kunjungan. Itu disebabkan oleh beberapa faktor diantaranya proses rujukan berjenjang yang belum berjalan secara optimal, rujukan terlambat, dan ketidaksiapan fasilitas di tingkat primer dan sekunder yang berdampak pada tingginya jumlah kematian pada tingkat rujukan tersier. Pada tahun 2015 sampai tahun 2017 jumlah kematian di IGD berkurang seiring dengan berkurangnya jumlah kunjungan pasien karena sistem rujukan berjenjang telah diberlakukan.

Terdapat permasalahan-permasalahan yang diakibatkan oleh tidak maksimalnya pelayanan medis, terbatasnya fasilitas dan pelayanan paripurna pasien yang kurang optimal, juga berbagai permasalahanpermasalahan lain yang terjadi di Rumah Sakit Umum Pusat Prof. Dr. R. D. Kandou Manado, seperti: 1) Kurang ramahnya perawat terhadap pasien; 2) Penyampaian informasi tentang penanganan medis kurang optimal; 3) Kurangnya tenaga perawat di Rumah Sakit Umum Pusat Prof. Dr. R. D. Kandou Manado; 4) Kelebihan beban kerja perawat; 5) Fasilitas bangunan yang sudah lama; 6) Kurang disiplin pegawai seperti sering terlambat dan kurangnya pengawasan; 7) Terhambatnya pelayanan dikarenakan tidak tersedianya alat dan bahan habis pakai; 8) Sarana dan prasarana belum maksimal tersedia; 9) Terjadi perubahanperubahan teknologi alat medis tapi kompetensi dari tenaga medis masih kurang.

Dari berbagai permasalahan yang terjadi di Rumah Sakit Umum Pusat Prof. Dr. R. D. Kandou Manado dapat dilihat bahwa kinerja dari pegawai tidak maksimal karena kurangnya sarana dan prasarana pendukung dalam melayani pasien dan fungsi pengawasan yang tidak berjalan dengan baik akibatnya banyak keluhan dan masalah dari masyarakat sehingga berdampak pada kualitas pelayanan Rumah Sakit Umum Pusat Prof. Dr. R. D. Kandou Manado, untuk itu peneliti merasa perlunya pemberian remunerasi, manajemen perubahan dan budaya organisasi, agar kualitas pelayanan dan kinerja pegawai meningkat dan fungsi pengawasan lebih optimal supaya setiap pegawai/individu memiliki kesadaran atau dapat berubah untuk lebih bertanggung jawab dalam kedisiplinan. Serta meningkatkan sarana dan prasarana dalam bidang teknologi agar kinerja setiap pegawai dapat optimal dalam melayani masyarakat.

Budaya organisasi juga berperan penting dalam meningkatkan kinerja pegawai karena budaya organisasi dapat mempengaruhi kesadaran dan kedisiplinan masing-masing pegawai, sehingga kinerja pegawai Rumah Sakit Umum Pusat Prof. Dr. R. D. Kandou Manado dapat memberikan pelayanan yang bermutu serta profesional agar menjangkau seluruh lapisan masyarakat 


\section{TINJUAN PUSTAKA}

\section{Manajemen Sumber Daya Manusia}

Manusia merupakan sumber daya yang paling penting dalam mencapai keberhasilan dalam suatu organisasi. Kemajuan-kemajuan diberbagai bidang antara lain bidang teknologi menyebabkan perubahan dalam cara kerja dan usaha mencapai tujuan tertentu. Terbatasnya sumber-sumber kebutuhan manusia yang di perlukan dalam proses pencapaian usaha, menuntut dilaksanakannya cara kerja yang efektif dan efisien.

Karami (2001) dalam tulisannya menjelaskan manajemen sumber daya manusia strategis merupakan suatu kunci bagi perusahaan untuk memperolah persaingan yang berkelanjutan dengan mengintegrasikan manajemen sumber daya manusia dan strategi bisnis.

Manajemen sumber daya manusia merupakan bagian tak terpisahkan dari manajemen suatu organisasi. Kegunaan manajemen sumber daya manusia adalah untuk meningkatkan konstribusi orang pada organisasi dalam cara-cara yang strategis, etis dan sosial dapat dipertanggung jawabkan. Manajemen sumber daya manusia memberikan sumbangan secara langsung pada peningkatan produktivitas melalui penemuan cara-cara yang lebih efisien dan efektif untuk mencapai tujuan dan secara tidak langsung melalui peningkatan mutu kehidupan kerja karyawan.

\section{Remunerasi}

Para ahli menjelaskan beberapa konsep tentang definisi remunerasi diantaranya Jusmaliani (2011:122) remunerasi tidak hanya terbatas pada gaji atau upah, melainkan meliputi pula berbagai manfaat yang diperoleh oleh karyawan, baik dalam bentuk uang maupun non uang. Menurut Milkovich dan Newman (1999) menyebutkan bahwa remunerasi mengacu kepada segala bentuk keuntungan baik bersifat finansial (transaksional) maupun non finansial (relasional). Menurut Thoha (2010:38) remunerasi dikaitkan dengan penataan kembali sistem penggajian pegawai yang didasarkan pada penilaian kinerja, dengan tujuan terciptanya sistem tata kelola pemerintah yang baik dan bersih. Menurut Hasibuan (2012:118) remunerasi merupakan semua pendapatan yang berbentuk uang, barang langsung atau tidak langsung yang diterima pegawai sebagai imbalan jasa yang diberikan kepada perusahaan. Saputra (2014) tunjangan kinerja merupakan penghasilan yang diberikan kepada pegawai berdasarkan kehadiran dan prestasi kerja dalam bentuk uang selain gaji pokok, tunjangan jabatan dan tunjangan lainnya yang berlaku nasional yang ditetapkan pemerintah. Remunerasi adalah upah dan segala macam bentuk manfaat financial lainnya yang diterima seseorang sebagai hasil dari sesuatu pekerjaan tertentu. Rosenberg (1993). Remunerasi adalah suatu bentuk pemberian prestasi balasan (balas jasa) atau hadiah, khususnya untuk jasa yang sudah digunakan. Komarudin (1983).

Menurut Kementerian Pendayagunaan Aparatur Negara maksud pemberian remunerasi untuk mendorong sumber daya manusia bertumbuh menjadi manusia berkualitas dan membentuk sumber daya manusia dengan perilaku yang berorientasi pada pelayanan serta mengurangi tindak korupsi, kolusi dan nepotisme $(\mathrm{KKN})$ selain itu sistem remunerasi diharapkan dapat menciptakan persaingan positif antara pegawai, akan terlihat mana yang pemalas dan seterusnya, sehingga akan terpacu suasana dan semangat untuk membangun dan mengembangkan diri.

\section{Manajemen Perubahan}

Perubahan selalu terjadi, disadari atau tidak. Begitu pula halnya dengan organisasi. Organisasi hanya dapat berubah jika dapat melakukan perubahan. Setiap perubahan lingkungan yang terjadi harus dicermati karena keefektifan suatu organisasi tergantung pada sejauh mana organisasi dapat menyesuaikan diri dengan 
perubahan tersebut. Manajemen perubahan adalah suatu proses secara sistematis dalam menerapkan pengetahuan, sarana dan sumber daya yang diperlukan untuk mempengaruhi perubahan pada orang yang akan terkena dampak dari proses perubahan tersebut Wibowo (2011:193). Aradea dkk (2010: E-27) mengatakan bahwa Change Management adalah serangkaian proses yang digunakan untuk memastikan bahwa perubahan strategis yang signifikan dalam organisasi dilakukan secara terkontrol dan sistematis, untuk mengatasi resistensi terhadap perubahan dalam rangka meningkatkan keterlibatan dan pencapaian tujuan organisasi untuk transformasi efektif. Perubahan organisasional dapat dilihat sebagai produk dari tiga produk organisasi yang bersifat interdependen, antara lain: (1) The choice process yang berkaitan dengan sifat, lingkup, dan focus pengambilan keputusan. (2) The trajectory process yang berhubungan dengan masa lalu organisasi dan arah masa depan dan hal tersebut terlihat seperti hasil dari visinya, maksud dan tujuan masa depan. (3) The change process yang mencakup pendekatan pada mekanisme untuk mencapai, dan hasil perubahan Wibowo (2011:203).

Perubahan jenis pertama sebagai "Smooth Incremental Change "dimana perubahan terjadi secara lambat, sistematis dan dapat diprediksikan. Jenis perubahan yang kedua adalah "bumpy incre mental change" perubahan ini dicirikan sebagai priode relatif tenang yang sekali-sekali disela percepatan gerak perubahan. Pemicu perubahan jenis ini selain mencakup perubahan lingkungan organisasi, juga bisa bersumber dari perubahan internal seperti tuntutan peningkatan efisiensi dan perbaikan metode kerja. Contohnya, reorganisasi yang secara periodik dilakukan perusahaan. Jenis perubahan yang ketiga adalah "discontinuous change" yang didefinisikan sebagai perubahan yang ditandai oleh pergeseran-pergeseran cepat atas strategi, struktur, atau budaya atau ketiganya sekaligus Sulaksana (2004 :35).

\section{Budaya Organisasi}

Budaya organisasi adalah sistem makna bersama yang dianut oleh anggota-anggota yang membedakan organisasi itu dari organisasi-organisasi lain (Robbins 2006:721). Budaya mampu mengumpulkan dan membelokkan dampak perubahan organisasi yang sudah direncanakan secara matang, pada dasarnya budaya perusahaan menjelma dalam berbagai wujudnya dan karenanya bisa mendukung atau menghambat perubahan. Budaya organisasi merupakan pola keyakinan dan nilai-nilai dalam organisasi yang dipahami, dijiwai, dan dipraktekkan oleh anggota organisasinya sehingga pola tersebut memberikan makna tersendiri bagi organisasi yang bersangkutan dan menjadi dasar aturan berperilaku. Sobrin (2005). Hal ini berarti setiap organisasi mempunyai sistem makna yang berbeda. Perbedaan ini menyebabkan setiap organisasi mempunyai karakteristik yang unik dan berbeda serta respon yang berbeda ketika menghadapi masalah yang sama. Disamping itu perbedaan sistem makna ini dapat menyebabkan perbedaan perilaku para anggota organisasi dan perilaku organisasi itu sendiri. Akar perbedaan ini bersumber pada asumsiasumsi dasar yang meliputi keyakinan, nilai-nilai, filosofi atau ideology organisasi yang digunakan dalam memecahkan persoalan organisasi.

Keberhasilan perubahan budaya organisasi salah satunya bergantung pada kuat atau tidaknya budaya yang sekarang ada sehingga dapat dikatakan bahwa mengubah budaya bukanlah pekerjaan yang gampang. Dari sudut waktu, perubahan dapat menghabiskan 5 sampai 10 tahun, itupun tingkat keberhasilannya masih dipertanyakan karena respon pegawai terhadap perubahan sangat bervariasi. Sobirin (2005). Faktor lain yang mempengaruhi keberhasilan perubahan budaya adalah kemauan para anggota organisasi untuk berpartisipasi dalam perubahan.

\section{Kinerja Pegawai}

Kinerja merupakan suatu bentuk usaha kegiatan atau program yang diprakarsai dan dilaksanakan oleh pimpinan organisasi atau perusahaan untuk mengarahkan dan mengendalikan prestasi karyawan (Ruky, 2010:6). Mangkunegara (2011: 67, dalam koesmono 2005) kinerja dapat didefinisikan sebagai hasil kerja 
secara kualitas dan kuantitas yang dapat dicapai oleh seseorang pegawai dalam melaksanakan tugas sesuai dengan tanggung jawab yang diberikan kepadanya. Kinerja karyawan mengacu pada prestasi kerja karyawan diukur berdasarkan standar atau citra yang ditetapkan perusahaan. Pengelolaan untuk mencapai kinerja karyawan yang sanggat tinggi terutama untuk meningkatkan kinerja perusahaan secara keseluruhan. Kinerja karyawan adalah hasil yang diinginkan dari pelaku Menurut Mathis (2006:13) faktor yang mempengaruhi kinerja karyawan yaitu kemampuan karyawan untuk pekerjaan. Keberhasilan suatu organisasi dalam rangka mencapai tujuan tergantung dari kemampuan dan keandalan sumber daya manusia yang mengoperasikan unit-unit kerja yang terdapat didalam organisasi bersangkutan. Untuk itu diperlukan kinerja yang tinggi dari pelaku-pelaku kegiatan tersebut. Kinerja adalah kesediaan seseorang atau kelompok orang untuk melakukan sesuatu kegiatan dan menyempurnakannya sesuai dengan tanggung jawab dan hasil seperti yang diharapkan. Rivai dan basri (2005: 14). mengatakan: "Kinerja (performance) adalah hasil yang di inginkan dari perilaku. Bambang guritno dan waridin (2005:63) mengatakan bahwa "Kinerja merupakan perbandingan hasil kerja yang dicapai oleh karyawan dengan standar yang telah ditentukan.

Mahsun, dalam bukunya Pengukuran Kinerja Sektor Publik (2006:25) menjelaskan "Kinerja (performance) adalah gambaran mengenai tingkat pencapaian pelaksanaan suatu kegiatan atau program dalam mewujudkan sasaran, tujuan, misi, dan visi organisasi yang tertuang dalam strategi planning organisasi”.

\section{METODOLOGI}

Jenis Penelitian yang digunakan dalam penelitian ini adalah penelitian kuantitatif. Metode penelitian kuantitatif sebagai metode penelitian yang berdasarkan pada filsafat positivisme, digunakan untuk meneliti pada populasi atau sampel tertentu. Penelitian ini bertempat di Rumah Sakit Umum Pusat Prof. Dr. R. D. Manado. Adapun Waktu penelitian Bulan Desember Tahun 2019 sampai Mei Tahun 2020. Teknik pengumpulan data dengan melakukan interview dan penyebaran angket kepada responden.

Target Populasi yang diambil dalam penelitian ini adalah Aparatur Sipil Negara Rumah Sakit Umum Prof. Dr. R. D. Manado. Dan jumlah populasi ASN yang di ambil yaitu sebanyak 150 orang (Data Tahun 2019), dengan jumlah sampel yang diambil sebanyak 60 Responden. Alat analisis yang digunakan dalam penelitian ini adalah regresi linear berganda dengan bantuan pengujian alat analiis SPSS 23 Minitab for Windows.

\section{HASIL DAN PEMBAHASAN}

RSUP Prof. Dr. R.D.Kandou Manado merupakan UPT yang berada di bawah dan bertanggung jawab kepada Direktur Jenderal dan secara administratif dikoordinasikan dan dibina oleh sekretaris Direktorat Jenderal dan secara teknis fungsional dibina oleh direktur di lingkungan Direktorat Jenderal sesuai dengan tugas dan fungsinya.

Komposisi Responden berdasarkan Umur, Masa Kerja, Status Perkawinan, Pendidikan,dan Jabatan

\begin{tabular}{llll}
\hline No & Karakteristik & Golongan & Jumlah \\
\hline 1. & Jenis kelamin & Pria & 16 \\
& & Wanita & 44 \\
\hline & Jumlah & 60 \\
\hline 2. & Umur & $25-30$ tahun & 15 \\
& & $31-35$ tahun & 20 \\
& & $36-40$ tahun & 15 \\
& $\geq 40$ tahun & 10 \\
\hline
\end{tabular}




\begin{tabular}{llll}
\hline & & Jumlah & 60 \\
\hline 3. & Masa Kerja & $\leq 5$ tahun & 6 \\
& $6-10$ tahun & 14 \\
& $11-15$ tahun & 21 \\
& $16-20$ tahun & 15 \\
& $\geq 20$ tahun & 4 \\
\hline & Jumlah & 60 \\
\hline 4. & Tingkat Pendidikan & SMA/SMK Sederajat & 5 \\
& & Diploma & 20 \\
& Sarjana & 30 \\
& Magister & 5 \\
\hline & Jumlah & 60 \\
\hline
\end{tabular}

Sumber : Data Hasil Olahan (2020)

Tabel. Analisis Regresi Linier Berganda

\begin{tabular}{|c|c|c|c|c|}
\hline \multicolumn{5}{|c|}{ Coefficients $^{\mathrm{a}}$} \\
\hline \multirow{2}{*}{\multicolumn{2}{|c|}{ Model }} & \multicolumn{2}{|c|}{$\begin{array}{l}\text { Unstandardized } \\
\text { Coefficients }\end{array}$} & \multirow{2}{*}{$\begin{array}{c}\text { Standardized Coefficients } \\
\text { Beta }\end{array}$} \\
\hline & & $\mathrm{B}$ & $\begin{array}{l}\text { Std. } \\
\text { Error }\end{array}$ & \\
\hline \multirow[t]{4}{*}{1} & (Constant) & 1.572 & 2.466 & \\
\hline & $\begin{array}{l}\text { Remuneras } \\
\mathrm{i}\end{array}$ & .618 & .097 & .565 \\
\hline & $\begin{array}{l}\text { Manajeme } \\
\mathrm{n} \\
\text { Perubahan }\end{array}$ & .618 & .097 & .565 \\
\hline & $\begin{array}{l}\text { Budaya } \\
\text { organisasi }\end{array}$ & 209 & .050 & .370 \\
\hline
\end{tabular}

a. Dependent Variable: Kinerja Pegawai

Sumber : Data primer diolah, 2020

Berdasarkan tabel di atas, maka persamaan regresi linear berganda dengan 3 variabel independen sebagai berikut:

$\mathrm{Y}=\mathbf{a}+b_{1} \cdot \mathrm{X}_{1}+\boldsymbol{b}_{2} \cdot \mathrm{X}_{2}+\boldsymbol{b}_{3} \cdot \mathrm{X}_{3}+\mathrm{e}$

$Y=1.572+0,618 X_{1}+0,618 X_{2}+0,209 X_{3}+e$

$\mathrm{Y}=1,572+0,618$ Remunerasi $+0,618$ Manajemen perubahan $+0,209$ Budaya Organisasi $+e$

Persamaan regresi tersebut dapat dijelaskan sebagai berikut:

1. Konstanta sebesar 1.572 artinya jika Remunerasi $\left(X_{1}\right)$ Manajemen Perubahan $\left(X_{2}\right)$ dan Budaya organisasi $\left(\mathrm{X}_{2}\right)$, bernilai Nol, maka nilai variabel dependen Kinerja Pegawai adalah sebesar 1.572.

2. Nilai koefisien Remunerasi $\left(\mathrm{X}_{1}\right)$ sebesar 0,618 , dan memiliki koefisien regresi paling dominan. Artinya variable Remunerasi memiliki pengaruh paling besar terhadap kinerja pegawai jika variabel independen lain nilainya tetap dan Remunerasi $\left(\mathrm{X}_{1}\right)$ mengalami kenaikan 1 point atau $1 \%$, maka Kinerja Pegawai (Y) akan mengalami kenaikan sebesar 0,618 per 1 point/ $1 \%$. Koefisien bernilai positif artinya terjadi hubungan positif antara $\mathrm{X}_{1}$ dan $\mathrm{Y}$, semakin naik $\mathrm{X}_{1}$ maka $\mathrm{Y}$ akan semakin naik.

3. Nilai koefisien Manajemen Perubahan $\left(\mathrm{X}_{2}\right)$ sebesar 0,618, dan memiliki koefisien regresi paling dominan. Artinya variabel manajemen perubahan memiliki pengaruh paling besar terhadap kinerja 
pegawai jika variabel independen lain nilainya tetap dan manajemen Perubahan $\left(\mathrm{X}_{2}\right)$ mengalami kenaikan 1 point atau 1\%, maka Kinerja Pegawai (Y) akan mengalami kenaikan sebesar 0,618 per 1 point/ $1 \%$. Koefisien bernilai positif artinya terjadi hubungan positif antara $\mathrm{X}_{2}$ dan $\mathrm{Y}$, semakin naik $\mathrm{X}_{2}$ maka $\mathrm{Y}$ akan semakin naik.

4. Nilai koefisien variabel Budaya Organisasi $\left(\mathrm{X}_{3}\right)$ sebesar 0,209 Artinya variabel Budaya Organisasi memiliki pengaruh terhadap kinerja pegawai. Nilai koefisien regresi adalah positif, artinya jika variabel independen lain nilainya tetap dan Budaya organisasi $\left(\mathrm{X}_{3}\right)$ mengalami kenaikan 1 poin atau 1\%, maka Kinerja pegawai (Y) akan mengalami peningkatan sebesar 0,209. Koefisien bernilai positif artinya terjadi hubungan positif antara $\mathrm{X}_{3}$ dan $\mathrm{Y}$, semakin naik $\mathrm{X}_{3}$ maka $\mathrm{Y}$ akan semakin naik.

Tabel. Hasil Uji Simultan (F)

\begin{tabular}{llrrrrr}
\hline \multicolumn{7}{c}{ ANOVA $^{\text {a }}$} \\
\hline \multirow{2}{*}{ Model } & $\begin{array}{l}\text { Sum of } \\
\text { Squares }\end{array}$ & df & $\begin{array}{c}\text { Mean } \\
\text { Square }\end{array}$ & F & Sig. \\
\hline & $\begin{array}{l}\text { Regressio } \\
\mathrm{n}\end{array}$ & 468.315 & 3 & 234.157 & 54.562 & $.000^{\mathrm{b}}$ \\
\cline { 2 - 7 } & Residual & 244.619 & 57 & 4.292 & & \\
\cline { 2 - 7 } & Total & 712.933 & 59 & & & \\
\hline
\end{tabular}

a. Dependent Variable: Kinerja Pegawai

b. Predictors: (Constant), Remunerasi, Manajemen perubahan, Budaya organisasi

Sumber: Data primer (2020)

5. Berdasarkan tabel 5.16 di atas, terlihat nilai $\mathrm{F}$ hitung sebesar 54,562 dengan probabilitas signifikansi sebesar 0,000 . Terlihat bahwa nilai probabilitas signifikansi tersebut lebih kecil dari 0,05. Dengan demikian berarti $\mathrm{H}_{\mathrm{o}}$ ditolak dan $\mathrm{H}_{\mathrm{a}}$ diterima. Artinya Hipotesis Pertama yang menyatakan bahwa "Remunerasi, Manajemen Perubahan dan Budaya organisasi diduga secara bersama (simultan) berpengaruh terhadap Kinerja Pegawai" terbukti/ diterima. Kesimpulannya adalah bahwa variable Remunerasi $\left(\mathrm{X}_{1}\right)$ Manajemen Perubahan $\left(\mathrm{X}_{2}\right)$ dan Budaya Organisasi $\left(\mathrm{X}_{3}\right)$, secara bersama-sama (simultan) berpengaruh terhadap Kinerja Pegawai (Y).

Tabel Hasil Uji Parsial (t)

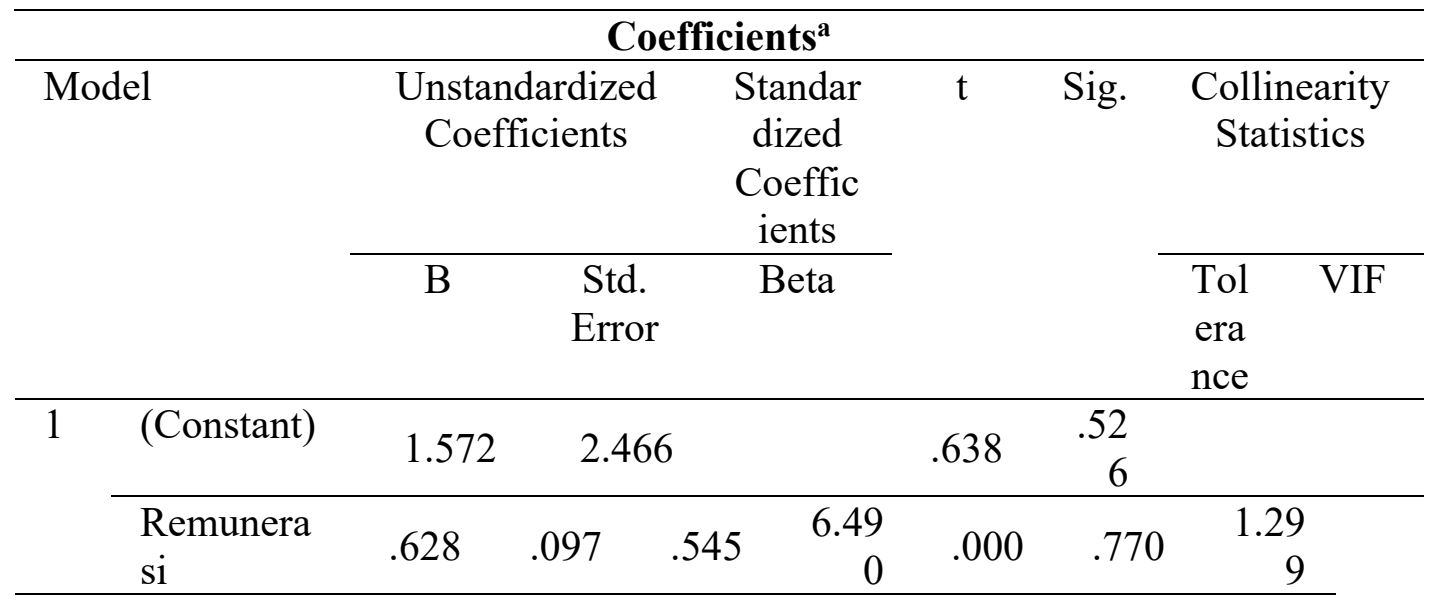




\begin{tabular}{|c|c|c|c|c|c|c|c|}
\hline $\begin{array}{l}\text { Manajeme } \\
\mathrm{n} \\
\text { Perubahan }\end{array}$ & .618 & .097 & .565 & $\begin{array}{r}6.39 \\
0\end{array}$ & $\begin{array}{r}.00 \\
0\end{array}$ & $\begin{array}{r}.77 \\
0\end{array}$ & $\begin{array}{r}1.29 \\
9\end{array}$ \\
\hline $\begin{array}{l}\text { Budaya } \\
\text { Organisasi }\end{array}$ & .209 & .050 & .370 & $\begin{array}{r}4.18 \\
8\end{array}$ & $\begin{array}{r}.00 \\
0\end{array}$ & $\begin{array}{r}.77 \\
0\end{array}$ & $\begin{array}{r}1.29 \\
9\end{array}$ \\
\hline
\end{tabular}

a. Dependent Variable: Kinerja_Pegawai

Sumber: Data primer (2020)

Berdasarkan tabel 5.17. di atas, dapat ditarik kesimpulan sebagai berikut:

1. Dari tabel telihat bahwa nilai koefisien regresi Remunerasi memiliki tingkat sigifikansi 0,000 , nilai ini lebih kecil dari 0,05 atau nilai sig $>\alpha$, ini berarti hipotesis penelitian yang menyatakan "Remunerasi diduga secara parsial berpengaruh terhadap Kinerja Pegawai” diterima. Selain menggunakan nilai probabilitas atau nilai sig, metode yang lain yang dapat digunakan adalah dengan menggunakan nilai $\mathrm{t}$ hitung dibandingkan dengan nilai t tabel. Dalam kasus ini, thitung memiliki nilai 6.490 sedangkan t tabel 1,572, ini berarti thitung $>t$ tabel sehingga hipotesis 2 dalam penelitian diterima. Kesimpulannya adalah bahwa variable Remunerasi secara parsial berpengaruh terhadap kinerja pegawai.

2. Dari tabel terlihat bahwa nilai koefisien regresi Manajemen perubahan memiliki tingkat sigifikansi 0,000, nilai ini lebih kecil dari 0,05 atau nilai sig $>\alpha$, ini berarti hipotesis penelitian yang menyatakan "Manajemen Perubahan diduga secara parsial berpengaruh terhadap Kinerja Pegawai” diterima. Selain menggunakan nilai probabilitas atau nilai sig, metode yang lain yang dapat digunakan adalah dengan menggunakan nilai t hitung dibandingkan dengan nilai t tabel. Dalam kasus ini, $t$ hitung memiliki nilai 6.390 sedangkan $t$ tabel 1,572, ini berarti $t$ hitung $>t$ tabel sehingga hipotesis 2 dalam penelitian diterima. Kesimpulannya adalah bahwa variabel manajemen perubahan secara parsial berpengaruh terhadap kinerja pegawai.

3. Dari tabel telihat bahwa nilai koefisien regresi budaya organisasi memiliki tingkat sigifikansi 0,000 , nilai ini lebih kecil dari 0,05 atau nilai sig $<\alpha$, ini berarti hipotesis 3 dalam penelitian ini yang menyatakan "budaya organisasi diduga berpengaruh terhadap kinerja pegawai" diterima. Selain menggunakan nilai profitabilitas atau nilai sig, metode yang lain yang dapat digunakan adalah dengan menggunakan nilai $t$ hitung dibandingkan dengan nilai t tabel. Dalam kasus ini, t hitung memiliki nilai 4.188 sedangkan $t$ tabel 1,572. Ini berarti thitung $>$ t tabel sehingga hipotesis penelitian diterima. Kesimpulannya adalah bahwa variabel budaya organisasi secara parsial berpengaruh terhadap kinerja pegawai

\section{Pengaruh Penerapan Remunerasi, Manajemen Perubahan dan Budaya Organisasi Terhadap Kinerja Pegawai}

Hasil penelitian menunjukan bahwa Remunerasi, Manajemen Perubahan dan Budaya Organisasi berpengaruh signifikan terhadap kinerja pegawai RSUP Prof Dr. R.D. Kandou Manado. Semakin baik penerapan Remunerasi, manajemen perubahan dan budaya organisasi yang dimiliki RSUP Prof Dr. R.D. Kandou Manado maka akan semakin meningkatkan kinerja pegewai, karena penerapan remunerasi, manajemen perubahan dan budaya organisasi sangat berpengaruh untuk keberhasilan suatu organisasi dan dengan penerapan remunerasi, manajemen perubahan dan budaya organisasi para pegawai akan lebih termotivasi, antusias untuk bekerja karena penerapan remunerasi, manajemen perubahan dan budaya organisasi memiliki indikator yang dapat merubah kondisi suatu organisasi ke arah yang lebih baik serta produktif dan tentunya akan berakibat membuat para pegawai lebih termotivasi dan antusias dalam bekerja, baik itu perubahan kesejahteraan, perubahan struktur, perubahan teknologi, perubahan individu, orientasi tim, orientasi orang, kreativitas/inovasi dan pengambilan resiko, perhatian terhadap detail, orientasi hasil, keagresifan dan kemantapan itu adalah indikator yang sangat mempengaruhi kinerja para pegawai jika di terapkan maka kinerja pegawai pada RSUP Prof Dr. R.D. Kandou Manado akan lebih baik lagi dari kinerja 
sebelumnya. Ini menunjukan bahwa variabel Remunerasi, Manajemen Peubahan dan Budaya Organisasi secara bersama (simultan) berpengaruh positif dan signifikan terhadap Kinerja Pegawai.

\section{Pengaruh Penerapan Remunerasi Terhadap Kinerja Pegawai}

Hasil penelitian menunjukan bahwa Remunerasi berpengaruh singnifikan dan Remunerasi merupakan variabel yang pengaruhnya paling besar terhadap kinerja pegawai pada RSUP Prof Dr. R.D. Kandou Manado. Hal ini berarti semakin baik penerapan remunerasi yang dilakukan oleh pihak RSUP Prof Dr. R.D. Kandou Manado, maka kinerja pegawai juga akan semakin baik. Adanya pengaruh penerapan remunerasi secara finansial seperti dapat dilihat dari besaran gaji yang diberikan, besaran tunjangan yang diberikan, kemudian remunerasi secara non finansial seperti dapat dilihat dari tanggung jawab yang diberikan sesuai kemampuan dan penerapan promosi jabatan sesuai dengan prestasi pegawai. Berdasarkan hasil yang didapat bahwa indikator yang mengindikasikan peranan terbesar dalam mengukur penerapan remunerasi di RSUP Prof Dr. R.D. Kandou Manado dengan nilai estimate tertinggi adalah besaran tunjangan yang diberikan. Sedangkan indikator yang memiliki nilai indikator yang paling besar dalam mengukur kinerja pegawai dengan nilai estimate tertinggi adalah adanya kualitas atas pekerjaan yang diberikan oleh pimpinan karena hal ini merupakan tanggung jawab yang diberikan organisasi kepada setiap pegawai. Hal tersebut menunjukan bahwa besaran tunjangan yang diberikan oleh pihak RSUP Prof Dr. R.D. Kandou Manado mempunyai pengaruh positif terhadap kinerja setiap pegawai dalam kualitas atas pekerjaan yang diberikan. Hal ini secara empiris didukung oleh penelitian yang dilakukan Maryesa (2016) tentang analisis peran remunerasi dan budaya organisasi terhadap kompetensi pegawai guna meningkatkan kinerja pegawai di Lembaga Penerbangan dan Antariksa Nasional dimana pengaruh remunerasi terhadap kinerja pegawai pada LAPAN dapat diterima. Selanjutnya, penelitian ini didukung oleh Nasution (2019) dimana remunerasi, motivasi dan kepuasan kerja mempunyai pengaruh terhadap kinerja pegawai Universitas Islam Negeri Sumatera Utara Medan.

\section{Pengaruh Manajemen Perubahan Terhadap Kinerja Pegawai}

Hasil penelitian menunjukan bahwa manajemen perubahan berpengaruh singnifikan dan manajemen perubahan merupakan variabel yang pengaruhnya paling besar terhadap kinerja pegawai pada RSUP Prof Dr. R.D. Kandou Manado. Hal ini berarti semakin baik manajemen perubahan, maka kinerja pegawai juga akan semakin baik. Adanya pengaruh manajemen perubahan dapat dilihat dari kuantitas output, jangka waktu output, kehadiran ditempat kerja dan sikap kooperatif dalam menghadapi setiap manajemen perubahan yang ditetapkan perusahaan. Berdasarkan hasil yang didapat diketahui indikator yang mengindikasikan peranan terbesar dalam mengukur manajemen perubahan dengan nilai estimate tertinggi adalah perubahan struktur organisasi. Sedangkan indikator yang memiliki nilai indikator yang paling besar dalam mengukur kinerja pegawai dengan nilai estimate tertinggi 0,832 adalah adanya kualitas atas pekerjaan yang diberikan oleh pimpinan. Hal tersebut menunjukan bahwa perubahan dalam struktur organisasi yang dilakukan oleh pihak RSUP Prof Dr. R.D. Kandou Manado mempunyai pengaruh positif terhadap kinerja setiap pegawai dalam kualitas atas pekerjaan yang diberikan.

Hal ini secara empiris didukung oleh penelitian yang dilakukan Arifana (2014) "Pengaruh Manajemen Perubahan Terhadap Gaya Kepemimpinan serta Dampaknya pada Motivasi Kerja dan Kinerja Karyawan pada PT Bank Tabungan Pensiunan Nasional Purna Bakti cabang Jember. Penelitian ini juga didukung oleh Penelitian oleh Wanza (2016) tentang Influence of Change Management on Employee Performance: A Case of University of Eldoret, Kenya, yang menemukan bahwa Variabel Manajemen Perubahan mempengaruhi kinerja karyawan. Studi ini menemukan bahwa faktor manajemen perubahan (kepemimpinan,budaya,struktur dan teknologi) dipengaruhi kinerja karyawan. 


\section{Pengaruh Budaya Organisasi Terhadap Kinerja Pegawai}

Hasil penelitian menunjukan bahwa budaya Organisasi berpengaruh signifikan terhadap kinerja pegawai pada RSUP Prof Dr. R.D. Kandou Manado. Kondisi budaya organisasi yang baik akan meningkatkan kerjasama yang baik antar pegawai sehingga dapat membawa rumah sakit pada pencapaian tujuan dan kemajuan rumah sakit yang optimal. Budaya organisasi yang baik akan menimbulkan dampak yang positif bagi setiap pegawai sehingga membuat pegawai semakin enjoy dalam bekerja. Budaya organisasi yang buruk dapat berpengaruh tidak baik terhadap setiap pegawai karena dampaknya akan membuat para pegawai tidak nyaman dalam bekerja dan produktivitas pekerja menjadi menurun.

Hal ini secara empiris didukung oleh penelitian yang dilakukan oleh Sasingkelo (2016) "Pengaruh Gaya Kepemimpinan dan Budaya Organisasi terhadap Kinerja Karyawan Pada PT. Horiguchi Sinar Insani, yang menemukan bahwa Budaya organisasi adalah faktor yang paling dominan berpengaruh terhadap kinerja karyawan. Dengan kata lain kinerja karyawan akan meningkat sejalan dengan perbaikan budaya organisasi Pada PT. Horiguchi sinar Insani di Kabupaten Minahasa Utara Sulawesi Utara.

Berdasarkan pembahasan di atas secara keseluruhan bahwa Penerapan Remunerasi yang tepat sasaran, Pengelolaan Manajemen perubahan yang baik serta Budaya Organisasi yang baik akan berpengaruh signifikan terhadap peningkatan Kinerja Pegawai di RSUP Prof Dr. R.D. Kandou Manado, hal ini perlu menjadi perhatian bagi pimpinan RSUP Prof Dr. R.D. Kandou Manado karena memang pada dasarnya pegawai yang bekerja pada RSUP Prof Dr. R.D. Kandou Manado di pengaruhi oleh Penerapan Remunerasi, Manajemen Perubahan dan Budaya organisasi, dimana hal-hal dasar yang mempengeruhi kinerja diantaranya adalah pemberian gaji, tunjangan, promosi yang berkaitan tentunya dengan kesejahteraan pegawai dan keluarga mereka. Selanjutnya, perubahan teknologi yang baru di RSUP Prof Dr. R.D. Kandou Manado dimana alat-alat yang akan digunakan harus mengikuti perkembangan untuk meningkatkan hasil kinerja dari setiap karyawaan yang ada apalagi ini berbicara tentang Rumah sakit agar pelayanan dapat maksimal rumah sakit harus mengupgread peralatan-peralatan atau alat-alat yang ada, dan juga harus ada perubahaan dari setiap individu atau pegawai dalam sikap atau perilaku dimana setiap karyawan harus memiliki sikap kerja yang baik dan merubah nilai-nilai dari setiap individu yang tidak profesional seperti malas, sering datang terlambat, kurang bertanggung jawab itu harus di rubah ke arah yang lebih baik agar kinerja pegawai semakin meningkat dan baik. Begitu juga budaya organisasi sangat berpengaruh terhadap kinerja pegawai hal ini menunjukan bahwa budaya organisasi merupakan jati diri pegawai dan merupakan cermin dari kinerja pegawai, budaya organisasi yang sesuai dengan kondisi pegawai akan meningkatkan kinerja pegawai yang bersangkutan.

\section{Kesimpulan}

\section{KESIMPULAN DAN SARAN}

Adapun kesimpulan dalam penelitian ini yakni : Remunerasi, Manajemen Perubahan dan Budaya Organisasi secara bersama-sama berpengaruh signifikan terhadap kinerja pegawai di RSUP Prof. Dr. R.D. Kandou Manado, kemudian Remunerasi berpengaruh secara signifikan terhadap kinerja pegawai di RSUP Prof Dr. R.D. Kandou Manado, selanjutnya Manajemen perubahan berpengaruh secara signifikan terhadap kinerja pegawai di RSUP Prof. Dr. R.D. Kandou Manado serta Budaya organisasi berpengaruh secara signifikan terhadap kinerja pegawai pegawai di RSUP Prof. Dr. R.D. Kandou Manado

\section{Saran}


Berdasarkan kesimpulan, maka saran yang dapat diberikan yakni karena Penerapan Remunerasi berdampak langsung bagi Kinerja Pegawai, maka pihak RSUP Prof. Dr. R.D. Kandou Manado harus memperhatikan faktor pemberian gaji yang tepat waktu, pemberian tunjangan yang sesuai dengan kinerja pegawai serta pemberian promosi jabatan sesuai dengan prestasi kerja dari pegawai tersebut. Kemudian, Manajemen Perubahan berdampak langsung bagi Kinerja Pegawai, maka pihak RSUP Prof. Dr. R.D. Kandou Manado harus memperhatikan Manajemen yang ada. Artinya sebagai agen perubahan maka harus selalu memperbarui dan meningkatkan Manajemen perubahan yang ada di RSUP Prof. Dr. R.D. Kandou Manado sehingga dapat mempengaruhi Kinerja Pegawai. Rumah sakit harus lebih memperhatikan indikator perubahan individu karena merupakan indikator dengan nilai yang terendah. Rumah sakit harus lebih baik lagi mengawasi setiap individu-individu atau pegawai yang ada dalam melakukan pekerjaan agar pegawai dapat memiliki sikap kerja yang baik supaya rumah sakit dapat berkembang lebih maju. Selanjutnya, Budaya Organisasi di RSUP Prof. Dr. R.D. Kandou Manado berdampak langsung terhadap Kinerja Pegawai, oleh karena itu pihak RSUP Prof. Dr. R.D. Kandou Manado harus memperhatikan Budaya yang ada dari setiap pegawai. Rumah sakit harus lebih memperhatikan indikator orientasi hasil karena merupakan indikator dengan nilai terendah. Rumah sakit harus dapat mempertahankan atau lebih meningkatkan orientasi hasil agar setiap pegawai dapat terdorong untuk bekerja, dengan adanya orientasi hasil setiap pegawai yang berprestasi dapat lebih meningkatkan prestasi kerja mereka karena orientasi hasil berbicara tentang penilaian dan pemberian penghargaan untuk setiap pegawai yang berprestasi dengan ditingkatkannya orientasi hasil maka pegawai akan lebih semangat dan semakin baik dalam bekerja juga tentunya akan berpengaruh pada kinerja pegawai dalam meningkatkan kemajuan RSUP Prof. Dr. R.D. Kandou Manado.

Selanjutnya, Bagi peneliti kedepan diharapkan dapat memperbaiki keterbatasan yang ada dalam penelitian ini dan dapat mengembangkan penelitian ini dengan faktor lain atau variabel bebas lainnya yang mempengaruhi Kinerja Pegawai.

\section{DAFTAR PUSTAKA}

Arifana, D (2014) Pengaruh Manajemen Perubahan Terhadap Gaya Kepemimpinan Serta Dampaknya Pada Motivasi Kerja dan Kinerja Kariawan di PT. Bank Tabungan Pensiun Nasional Purna Bakti Cabang Jember. Jurnal,

Drucker, Peter F. (2001). The Practice of Management. New York: Harper \& Row Publisher.

Fisher,C,D., Schoenfeldt, L.F \& shaw, J.B (1993) Human resource management, 2th Ed,Hougton Minfin Company.

Hasibuan (2011) Management Sumber Daya Manusia. Cetakan ke enam belas, Edisi revisi Jakarta: Penerbit Bumi Askhara.

Handoko (1984) Management Jogjakarta:BFF.

Hao, M.J \& Yazdanifard, R (2015) How Effective Leadership Can Facilitate Change in Organizations through Improvement and Innovation. 
I Kadek, M.A \& A.A Sagung, K.D (2014) Pengaruh Budaya Organisasi Gaya Kepemimpinan dan Motivasi kerja Terhadap Kinerja Karyawan Pada Hotel Jimbran Puri Bali. Jurnal.

Ida, A.B \& agus,S (2008) Pengaruh Motivasi Kerja, Kepemimpinan dan Budaya Organisasi Terhadap Kepuasan Kerja Karyawan Serta Dampaknya Pada Kinerja Perusahan (Studi Kasus pada PT. Pei Hai Internasional Wirratama Indonesia). Jurnal manajement Vol 10, no 2, September 2008.

Katiandagho, C (2014) Pengaruh disiplin Kerja Kepemimpinan Dan Motivasi Terhadap Kinerja Pegawai pada PT. PLN (persero) Wilayah sulutenggo Area Manado. Jurnal Emba vol 2 no 3 september 2014. http://ejournal.usrat.ac.id/indeks.php/emba/articel/view/5919. Diakses pada 1 Desember 2019.

Koesmono, H.T (2005) Pengaruh Budaya Organisasi Terhadap Motivasi dan Kepuasan Kerja Serta Kinerja Karyawan pada Sub sektor Industri Pengelolahan Kayu Skala Menegah di Jawa Timur. Jurnal Manajement Vol 7 no 2 September 2005.

Karami, A.A (2011) Manajement Sumber Daya Manusia. Edisi Revisi. Cetakan Ke enam belas, Jakarta: Penerbit Bumi Askara.

Kansal, K.K (2016) Impact Of Organization Change On Employees Performance In Maruti Suzuki. International Journal Of Research in IT and Managem ent Vol 6 Issue 11 November 2016. http://euroasiapub.org Diakses pada 1 Desember 2019.

Keputusan Menteri Kesehatan Republik Indonesia Nomor: 625/Menkes/SK/V/2010 Tentang Pedoman Penyusunan Sistem Remunerasi Pegawai BLU Rumah Sakit.

Kurt, Lewin (1997) Resolving Social Cinfilicts:and, Field Theory In Social Science, American Psychological Association.

Massi, E.M, Kawet, L \& Sendoe, G (2017) Pengaruh Budaya Oganisasi, Kepemimpinan, dan Lingkungan keraja terhadap kinerja karyawan PT. Telkom, TBK Manado. https://ejournal.unsrat.ac.id/index.php/emba/article/viewFile/18286/18198. Diakses pada 5 Desember 2019.

Mondy, R. Wayne \& Noe III, Robert M. (1992). Human Resource Management (fifth Edition). USA : Allyn and Bacon.

Peraturan Pemerintah Nomor 23 Tahun 2005 Jo Peraturan Pemerintah Nomor 74 Tahun 2012 Tentang Pengelolaan Keuangan Badan Layanan Umum.

Rachmawati, I,K (2008) Manajemen Sumber Daya Manusia Jogjakarta: Penerbit Andi.

Robbins, P.S (2006) Perilaku Organisasi, jilid 1 Jakarta: Penerbit PT. Prendhalilindo. 
Sangadji Nini. 2015. Tesis : Implementasi Program Remunerasi Dalam Rangka Reformasi Birokrasi Dan Peningkatan Kinerja Aparatur Di Lingkungan Sekretariat Daerah Provinsi Maluku Utara. Yogyakarta : Magister Ilmu Pemerintahan Universitas Muhammadiyah Yogkarta.

Sugiyono. (2016). Metode Penelitian Kuantitatif, Kualitatif, dan R\&D. Bandung: Alvabeta.

Suhartanto, Dwi. (2014). Metode Riset Pemasaran Cetakan Pertama. Bandung: CV. Alvabeta.

Susetyo, W.E (2014) Pengaruh Budaya Organisasi dan lingkungan Kerja Terhadap Kepuasan Kerja dan Kinerja Karyawan Pada PT Bank Muamalat Indonesia Divisi Konsumer Area Cabang Surabaya. Jurnal Ekonomi \& Manajemen.

Tewal, B., Adolfina, Pandowo, P., \& Tawas, H. (2017) Perilaku organisasi.Penerbit CV. Patra Media Grafindo Bandung.

Tulung, J.E. (2017). Resource Availability and Firm's International Strategy as Key Determinants Of Entry Mode Choice. Jurnal Aplikasi Manajemen,15(1), 160-168Sugiyono (2014) Metodologi Penelitian Bisnis. Cetakan ke delapan belas juli 2014 Bandung Alfabeta.

Tulung, J. E., Saerang, I. S., \& Pandia, S. (2018). The influence of corporate governance on the intellectu al capital disclosure: a study on Indonesian private banks. Banks and Bank Systems, 13(4), 61-72

Wibo (2012). Aplikasi Praktis Spss Dalam Penelitian. Yogyakarta: Gava Media.

Wanza, L \& Nkuraru, K.J (2016) Influence of change Managent on Employee Performance A Case Of University of Eldoret Kenya. Vol 7 No 4 April 2016. Jurnal of Businis and Social Science.

Wayne, M. R \& Noe R.M (2005) Human Resource Management. Ninth Edition. USA: Prentice Hall.

Wilfred, O.N.,Elijah, C.M., Mutury, W. (2014) Effect of Remuneration On Employees Performance in the Ministry of Internal Security: A Case of kisii Country. 